\title{
Andrzej WOJTYNA*
}

\section{Decentralizacja finansów publicznych}

\author{
Decentralization may not always be a panacea. \\ Its costs are more certain than its benefits.
}

Rémy Prud'homme

\section{Uwagi wstępne}

W końcu lat 90. Polska zapoczątkowata istotne reformy sektora publicznego: 1. systemu emerytalnego, 2. organizacji terytorialnej kraju ${ }^{1}$, 3. stużby zdrowia, 4. edukacji. Biorq̨c pod uwagę stopień ich koncepcyjnego przygotowania, sposób wprowadzania oraz pierwsze doświadczenia, można sformutować kilka uwag:

- poszczególne reformy cechowały się różnym stopniem przygotowania. $\mathrm{Z}$ punktu widzenia efektywności reform bardzo istotne jest znalezienie modelu (modeli) stanowiących punkt odniesienia dla oceny wariantu najbardziej odpowiedniego dla Polski. Chodzi w tym przypadku nie tyle o model teoretyczny, ale raczej o zespół spójnych rozwiązań ekonomiczno-prawnych zastosowanych z powodzeniem za granicą. Równie ważne jest przygotowanie jednego spójnego dokumentu o charakterze nie tylko propagandowo-informacyjnym, ale i analitycznym, który zawiera rachunek kosztów i korzyści (również w przekroju międzyokresowym) i wokół którego może toczyć się dyskurs publiczny. Moźna stwierdzić, że warunek ten został spełniony właściwie tylko w przypadku reformy emerytalnej;

- reformy zostały skumulowane w czasie. Nie zostały przedstawione przez rząd przekonujące argumenty przemawiające za wprowadzeniem reform en bloc. Uzasadnione jest oczywiście stwierdzenie, że mniej więcej od po-

\footnotetext{
Autor jest pracownikiem naukowym Akademii Ekonomicznej w Krakowie i Instytutu Nauk Ekonomicznych PAN w Warszawie.

1 Decentralizacja sektora publicznego zostala zapoczątkowana w 1990 r. poprzez zmiany w systemie administracji publicznej i przywrócenie instytucji samorządu terytorialnego na szczeblu gminnym. Jednocześnie nastạpilo osłabienie administracji szczebla wojewódzkiego, co doprowadzilo do wykształcenia się nieracjonalnego, dychotomicznego podzialu administracji publicznej na samorządową (tij. gminną) i rządową, de facto - centralną [Brożek, 2000, s. 48-49]. Wprowadzony z dniem 1 stycznia 1999 r. trójszczeblowy podzial terytorialny kraju można traktować jako próbę dokończenia zmian zapoczątkowanych na początku lat 90.
} 
łowy lat 90. tempo zmian systemowych uległo spowolnieniu i że konieczne stało się ich przyspieszenie. Nie oznaczało to jednak, że najwłaściwszym rozwiązaniem jest wprowadzanie czterech reform w tym samym okresie, tym bardziej iż dodatkowo został przedstawiony projekt reformy systemu podatkowego, a inne elementy transformacji (prywatyzacja, restrukturyzacja) również wymagały zintensyfikowania działań. W zasadzie w ogóle niedyskutowane byly alternatywne warianty rozłożenia reform w czasie według określonych sekwencji. Z badań teoretycznych i empirycznych wiadomo natomiast, że z punktu widzenia tzw. ekonomii politycznej reform bardzo istotne jest to, czy i w jakiej sekwencji wprowadzane są reformy; każdy z wariantów cechuje się odmiennym stopniem poparcia spolecznego. Istnieją oczywiście argumenty przemawiające za skumulowaniem w czasie kilku reform. Ulegają one jednak wyraźnemu osłabieniu w sytuacji, gdy dany kraj nie dysponuje odpowiednio sprawnym systemem legislacyjnym oraz efektywnie działającą administracją państwową ${ }^{2}$. Co więcej, poszczególne reformy nie były w tym samym stopniu pilne. Trudno byłoby prawdopodobnie wykazać, że proces transformacji gospodarki i wzrost gospodarczy natrafily na barierę w postaci nieadekwatnej terytorialnej organizacji kraju;

- w zbyt małym stopniu uwzględniono warunki zewnętrzne wprowadzania reform. Przy skumulowaniu reform sektora publicznego w czasie krótkookresowe koszty dla budżetu są znaczne, natomiast korzyści (przy założeniu, że przyjęty model okaże się właściwy) pojawią się dopiero ze znacznym opóźnieniem. W sytuacji gdy przy sporządzaniu budżetu zdecydowanie dominuje perspektywa jednoroczna, niekorzystne szoki zewnętrzne mogą bardzo skomplikować proces wprowadzania reform. Okres stabilnego i wysokiego tempa wzrostu w Polsce w latach 1995-1997 spowodował, że w zbyt małym stopniu uwzględniono ryzyko wystąpienia takiego niekorzystnego szoku i w konsekwencji nie zarezerwowano w budżecie wystarczających środków na wprowadzanie reform. Timing okazał się rzeczywiście niefortunny. Kryzys rosyjski oraz spadek koniunktury w Europie Zachodniej wystąpił akurat w okresie najmniej sprzyjającym z punktu widzenia wprowadzanych reform.

Potencjalne długookresowe korzyści z właściwie zaprojektowanych i umiejętnie wprowadzonych reform sektora publicznego są z pewnością bardzo duże, aczkolwiek ich kwantyfikacja jest zadaniem bardzo trudnym. Podstawowy korzystny efekt wiąże się z możliwością przyspieszenia tempa wzrostu dzięki ograniczeniu zakresu redystrybucji dochodów poprzez budżet. Panuje raczej powszechne przekonanie, że w stosunku do osiągniętego poziomu dochodu per capita udział wydatków publicznych w PKB krajów Europy Środkowej jest zdecydowanie zbyt wysoki. Wysoki poziom wydatków implikuje wysoki po-

2 Sytuacja szczególnie siẹ komplikuje, jeśli w okresie reformowania poszczególnych elementów sektora publicznego (opieki zdrowotnej, edukacji itp.) wprowadzane są daleko idące zmiany w statusie urzędników państwowych i w terytorialnej organizacji kraju. 
ziom podatków (przy danym deficycie budżetowym), co ma negatywne konsekwencje dla podażowej strony gospodarki. Jeśli bowiem relacja wydatków publicznych do PKB jest w tych krajach podobna jak w wysoko rozwiniętych krajach OECD, a dochód per capita jest jednocześnie kilkakrotnie niższy, to oznacza to, że nawet wysoka stopa oszczędności w sektorze prywatnym (rzędu 30-35\%) pozwala uzyskać stopę inwestycji jedynie rzędu 15-20\% PKB, która jest zdecydowanie zbyt niska z punktu widzenia zmniejszania dystansu w stosunku do krajów najbardziej rozwiniętych zob. [szerzej From, 1996].

Z najnowszych badań [Begga i Wyplosza 1999] wynika, że w okresie 1992 -1997 15 krajom Europy Środkowej i Wschodniej udało się co prawda obniżyć udział wydatków publicznych z 44,9\% do $40,4 \%$ PKB, ale jest to nadal wskaźnik równy poziomowi występującemu w Europie Zachodniej (40,0\% w UE w 1997 r.). Spośród krajów postsocjalistycznych jedynie Bułgaria ma rzeczywisty wskaźnik niższy od oszacowanego na podstawie modelu uwzględniającego osiągnięty poziom PKB. Co istotne, Polska (obok Słowacji i Albanii) jest krajem, w którym rzeczywisty udział w największym stopniu przekracza udział estymowany.

Istnieje oczywiście kilka innych mechanizmów negatywnego oddziaływania wielkości sektora publicznego na długookresowe tempo wzrostu. Jak dotąd jednak wyniki badań empirycznych nie dają rozstrzygających rezultatów zob. szerzej m.in. [Slemrod, 1995]. Niektórzy specjaliści odnoszą się dlatego sceptycznie do tezy, że „rozmontowywanie” państwa dobrobytu ma korzystny wpływ na wzrost gospodarczy [Atkinson, 1996; Lindert, 1996]. Również w koncepcji „trzeciej drogi” pojawia się myśl, że państwo opiekuńcze o nowych jakościowo cechach nie musi pozostawać w sprzeczności ze wzrostem gospodarczym [Giddens, 1999].

Znaczenie poszczególnych mechanizmów będzie oczywiście różne w przypadku określonych elementów reformy sektora publicznego; będzie ono np. inne w przypadku reformy emerytalnej niż reformy szkolnictwa. W każdym przypadku odmienne będą też implikacje makroekonomiczne (m.in. ich rozkład w czasie oraz prawdopodobieństwo przewagi skutków pozytywnych nad negatywnymi). Rozmiary niniejszego opracowania nie pozwalają na uwzględnienie wszystkich czterech reform. Zdecydowano się na wybór tego elementu reform sektora publicznego, w przypadku którego stan wiedzy o potencjalnych skutkach makroekonomicznych jest stosunkowo ograniczony. Chodzi mianowicie o decentralizację finansów publicznych, która jest jednym z elementów decentralizacji terytorialnej organizacji kraju. Reforma ta budziła i nadal budzi wiele kontrowersji. Zdaniem niektórych specjalistów obecne wyzwania rozwojowe, związane przede wszystkim z procesem globalizacji, przemawiają silnie na rzecz reformy; jednocześnie sformułowane zostały istotne argumenty przeciwko przyjętym rozwiązaniem zob. szerzej [Gilowska, 1999]. Krytycznie oceniane są też wyniki pierwszego roku funkcjonowania reformy [Brożek 2000, s. 83-88] $]^{3}$. Charakterystyczne jest to, że w dyskusji nad decen-

3 Autorka formuluje m.in. wniosek, że „reforma samorzạdowa, chociaż z politycznego punktu widzenia została dokonana, to pod względem ekonomicznym jest fikcją prawną" (s. 85). 
tralizacją finansów publicznych w bardzo niewielkim stopniu odwoływano się do doświadczeń zagranicznych, a w przypadkach gdy to czyniono, punktem odniesienia były najczęściej kraje Unii Europejskiej. W tej sytuacji celowe wydaje się przybliżenie dyskusji, jaka toczy się za granicą na temat decentralizacji finansów publicznych i jej makroekonomicznych implikacji w odniesieniu do krajów na podobnym do Polski poziomie rozwoju.

\section{Sporne kwestie teoretyczne}

Przeprowadzenie reform polegających na decentralizacji władzy państwowej jest zdecydowanie łatwiejsze, jeśli w wyniku prowadzonych badań naukowych ukształtował się pewien konsens, szczególnie w wymiarze normatywnym. Jak zauważają [Burki, Perry i Dillinger, 1999, s. 17], potrzebna w tym zakresie wiedza wymaga równoległego wysiłku badawczego ze strony finansów publicznych, nauk politycznych oraz teorii organizacji. Dyscypliny te wypracowaly pewne ramy teoretyczne pozwalające na formulowanie zaleceń pod adresem polityki reform decentralizacyjnych. Finanse publiczne rozpatrują problem w kategoriach powiązania podstawowych funkcji (alokacyjnej, redystrybucyjnej i stabilizacyjnej) z określonym szczeblem władzy. W wymiarze ekonomii politycznej paradygmat finansów publicznych przyjmuje, że polityka na szczeblu lokalnym służy oczyszczaniu się lokalnego rynku dóbr i usług. W ujęciu tym, poprzez głosowanie, obywatele dokonują wyboru odpowiadającej im kombinacji świadczonych usług i poziomów podatków. Przyjmuje się w nim, że wszyscy obywatele mają jednakowy dostęp do działań politycznych oraz że politycy działają jako pełnomocnicy wyborców.

Nauki polityczne proponują bardziej realistyczny obraz procesu politycznego. Polityka jest traktowana jako narzędzie rozwiązywania konfliktów między grupami interesów; w sposób bardziej kompleksowy są też ujmowane motywy, jakimi kierują się politycy. Zachowanie polityków jest podporządkowane zdobyciu i utrzymaniu władzy; uwypuklona jest rola kluczowych okręgów wyborczych oraz przywództwa partyjnego jako czynników determinujących tempo kariery politycznej.

Z kolei teoria organizacji zwraca uwagę na problem bodźców i trudności, jakie pojawiają się, gdy jedna grupa (lokalni podatnicy) musi w realizacji swoich celów polegać na innej grupie (lokalni politycy). Konflikt może wynikać stąd, że interes podatników („mocodawców”) może różnić się od interesu polityków („pelnomocników”). Jeśli „pełnomocnicy” (agents) dysponują przewagą informacyjną, a jednocześnie ich działania trudno jest monitorować, to interes "mocodawców” (principals) może zostać zagrożony. Teoria organizacji próbuje przezwyciężyć ten tzw. problem agencji poprzez zaproponowanie rozwiązań instytucjonalnych, które pozwalają pogodzić interesy obydwu stron zob. szerzej np. [Milgrom i Roberts, 1992].

Koncentrując uwagę na perspektywie badawczej finansów publicznych należy zauwaźyć, że począwszy od klasycznej pracy [Musgrave'a, 1959] utrzymu- 
je się dosyć wyraźna rozbieżność między pozytywnym i normatywnym wymiarem analizy. Ponieważ w warstwie pozytywnej dominuje teoria wyboru publicznego, plynące z niej wnioski niełatwo jest pogodzić z bardziej tradycyjnym spojrzeniem na ekonomiczną rolę państwa charakterystycznym dla ujęcia normatywnego. Chociaż w ostatnich latach coraz częściej zwraca się uwagę na komplementarność obydwu ujęć zob.[ Cordes, 1997], to jednak przezwyciężenie wyraźnej dwutorowości w analizowaniu „fiskalnej roli państwa” wydaje się być kwestią dosyć odległą.

W perspektywie badawczej finansów publicznych kluczową rolę w analizowaniu problemu decentralizacji pełni model federalizmu fiskalnego. Zgodnie z tym modelem wywodzącym się z pracy [Musgrave'a, 1959], funkcja alokacyjna może zostać przyporządkowana niższemu szczeblowi władzy (regionalnemu lub lokalnemu), natomiast pozostałe dwie funkcje (stabilizacyjna i redystrybucyjna) powinny stanowić domenę szczebla centralnego. Mimo że to tradycyjne ujęcie jest w ostatnich latach dosyć często kwestionowane, to jednak liczba jego zwolenników jest nadal bardzo znaczna por. [Shah 1999, s. 38].

Za pozostawieniem funkcji stabilizacyjnej w gestii szczebla centralnego przemawiają następujące względy:

- szoki cykliczne mają zazwyczaj charakter ogólnokrajowy (symetryczny względem regionów), w związku z czym wymagają reakcji na szczeblu centralnym; ujmując to trochę inaczej - lokalne gospodarki nie dysponują niezależnymi środkami polityki monetarnej i są zbyt otwarte, by działania antycykliczne mogły być skuteczne,

- stabilność waluty wymaga koordynacji polityki pieniężnej i fiskalnej, co jest moźliwe jedynie wówczas, gdy obydwie prowadzone są na szczeblu centralnym,

- koszty polityki dlugu publicznego prowadzonej na szczeblu regionalnym byłyby wyższe, natomiast korzyści stawałyby się również udziałem innych regionów,

- monetyzacja lokalnego długu publicznego zwiększałaby presję inflacyjną i stwarzałaby zagrożenie dla stabilności cen.

Z kolei pozostawienie funkcji redystrybucyjnej na szczeblu centralnym uzasadniane jest tym, że próby niwelowania różnic w dochodach przez niższe szczeble władzy, mogą skłaniać grupy o wyższych dochodach do przenoszenia się do obszarów o niższych podatkach, a grupy o niższych dochodach do migracji do regionów o wyższym poziomie świadczeń społecznych. Co więcej, jeśli zróżnicowanie dochodów występuje między regionami, to określony stopień zmniejszenia nierówności można uzyskać w sposób bardziej efektywny, jeśli redystrybucja przeprowadzana jest między grupami ludzi, a nie między regionami ${ }^{4}$.

4 W najnowszym raporcie Banku Światowego [Entering 2000, s. 115] zwraca się jednak uwagę, że władze lokalne administrują niektórymi uslugami (podstawowa opieka zdrowotna, szkolnictwo, budownictwo, transport publiczny) o istotnych implikacjach w zakresie redystrybucji dochodów. Władze lokalne mogą również odgrywać ważną rolę we wprowadzaniu w życie polityki redystrybucyjnej zaprojektowanej i finansowanej na szczeblu centralnym. 
Zgodnie z modelem federalizmu fiskalnego, argumenty za decentralizacją są przekonujące tylko w przypadku funkcji alokacyjnej. Jeśli bowiem korzyści z określonego rodzaju dóbr i usług są zasadniczo ograniczone do danego obszaru, to możliwy będzie przyrost dobrobytu, jeśli ich poziom i struktura będzie odzwierciedlać zmiany w lokalnych preferencjach. Porównując koszty alternatywnych rozwiązań, lokalni konsumenci będą przejawiać swoje preferencje głosując na określonych polityków lub przenosząc się do innych regionów. Rolę efektywnego mechanizmu rynkowego zastępuje więc polityczny mechanizm alokacji, w którym oczyszczanie się lokalnego rynku dóbr usług dokonuje się w wyniku procesu politycznego lub przestrzennej mobilności obywateli ${ }^{5}$.

Podstawową rolę w budowaniu argumentów teoretycznych na rzecz decentralizacji funkcji alokacyjnej państwa odegrała pochodząca z połowy lat 50 . tzw. hipoteza Tiebouta. To wlaśnie ten autor sformalizował wspomnianą powyżej myśl, że podobnie jak w przypadku dóbr prywatnych, kiedy to konsumenci przejawiają swe preferencje po prostu kupując te, a nie inne towary, również w przypadku lokalnych dóbr publicznych dokonują oni wyboru, tyle że poprzez przenoszenie się do miejscowości, w której struktura tych dóbr lepiej odpowiada ich preferencjom. W myśl hipotezy Tiebouta, konkurencja między lokalnymi spolecznościami odgrywa w odniesieniu do lokalnych dóbr publicznych analogiczną rolę, jak konkurencja między producentami w przypadku dóbr prywatnych. Konkurencja między lokalnymi społecznościami (lub lokalnymi politykami) pełni więc w odniesieniu do lokalnych dóbr publicznych funkcję „niewidzialnej ręki" A. Smitha: dobra te będą wytwarzane w sposób efektywny i dostarczane zgodnie z preferencjami jednostek. „Głosowanie za pomocą nóg” staje się w modelu Tiebouta sposobem ujawniania przez konsumentów swoich preferencji w stosunku do lokalnych dóbr publicznych por. [Stiglitz 2000, s. 735-736] ${ }^{6}$.

Chociaż teoretyczne znaczenie hipotezy Tiebouta jest bardzo duże, to należy pamiętać, że jest ona oparta na następujących restrykcyjnych założeniach [Hughes i Smith, 1991]:

- występuje duża liczba jednostek terytorialnych (jurisdictions) oferujących wystarczająco szeroki zakres poziomu usług publicznych. W każdej jednostce musi być ponadto odpowiednia ilość pracowników, pozwalająca na efektywne świadczenie usług,

- geograficzna mobilność nie wiąże się z żadnymi kosztami i jest powodowana jedynie względami fiskalnymi,

- usługi publiczne są finansowane w każdej jednostce terytorialnej za pomocą podatków ryczałtowych równych krańcowemu kosztowi dostarczenia tych usług.

Jeśli powyższe założenia (szczególnie pierwsze dwa) nie są spełnione, to w modelu Tiebouta szybko pojawiają się wygrani i przegrani. W szczególno-

5 Mechanizmy te są zdecydowanie mniej sprawne w warunkach krajów rozwijających się [Enter 2000, s. 115].

- Lokalne dobra publiczne to te, z których korzyści są ograniczone do osób mieszkających w danej jednostce terytorialnej. 
ści, jeśli nie wszyscy mieszkańcy są mobilni, to zwiększenie się mobilności tylko części z nich niekoniecznie musi doprowadzić do ogólnej poprawy sytuacji. Osoby, które nie mogą się przeprowadzić znajdą się w niekorzystnej sytuacji ze względu na napływ nowych mieszkańców o silnie odmiennych preferencjach. Równieź działania podejmowane przez rząd, aby upodobnić rzeczywistą sytuację do warunków występujących w modelu (polegające na przykład na zwiększeniu liczby jednostek terytorialnych lub usuwających bariery migracji) mogą nie dać zamierzonych efektów, ponieważ zwiększy się zarówno liczba wygranych, jak i przegranych ${ }^{7}$.

Również [Stiglitz, 2000, s. 736-742] podkreśla, że przyjęte w modelu Tiebouta założenia w praktyce rzadko obowiązują, ponieważ niesprawności rynku mogą występować również w przypadku lokalnych dóbr publicznych. Autor ten zwraca m.in. uwagę na modyfikujące znaczenie uwzględnienia efektów zewnętrznych, ograniczonej liczby konkurujących ze sobą jednostek terytorialnych oraz negatywnych konsekwencji prowadzenia przez nie konkurencji za pomocą obniżania podatków. Na duże rzeczywiste niebezpieczeństwo konkurencji za pomocą podatków (które w modelu Tiebouta nie wystẹpuje) zwraca uwagę [Musgrave, 1997]. Jego zdaniem, będzie ona prowadzić do niewystarczającej bazy podatkowej, nierównomiernego obciążenia podatkami i potencjalnie zbyt niskiego poziomu świadczonych usług. Zdaniem Musgrave'a, w obliczu tych zagrożeń „zwięsszona odpowiedzialność podatkowa niższych szczebli władzy wymaga koordynacji, a nie konkurencji podatkowej".

Model Tiebouta nie oferuje więc jednoznacznych argumentów za decentralizacją. Sprawa jest tak czy inaczej trudna, ponieważ niewątpliwe korzyści z decentralizacji są ograniczone do raczej szczególnego przypadku, w którym decyzje są podejmowane przez grupy społeczne składające się z jednostek o jednakowych preferencjach. Przy większej heterogeniczności ludności niewiele form decentralizacji prowadzi w sposób jednoznaczny do wzrostu dobrobytu w sensie Pareto. Dlatego [Hughes i Smith 1991] uważają, podobnie jak cytowani wcześniej [Burki et al., 1999], że wskazówek co do właściwego przyporządkowania określonych funkcji różnych szczeblom władzy nie wystarczy poszukiwać w ramach tradycyjnego modelu federalizmu fiskalnego. Również i ich zdaniem, dobrym uzupełnieniem jest perspektywa badawcza przyjmowana w teorii agencji. W tym przypadku celem decentralizacji jest wykorzystanie dwu głównych zalet niewielkich jednostek terytorialnych: lepszej informacji i lepszej kontroli.

Przewaga informacyjna, jaką dysponują lokalni urzẹdnicy, pozwala na bardziej precyzyjne określenie celów. W zasadzie informacja ta mogłaby być przekazywana decydentom na szczeblu centralnym. Okazuje się jednak, że koszt przetwarzania informacji rośnie szybko wraz ze wzrostem wielkości organizacji.

Lepsza kontrola wynika z przewagi informacyjnej lokalnych wyborców. Decentralizacja polegająca na przekazaniu uprawnień lokalnej władzy samo-

7 Hughes i Smith uważają, że ze względu na przyjẹte w nim zalożenia model Tiebouta jest malo przydatny w poszukiwaniu rozwiązań w krajach Europy Zachodniej. 
rządowej, a nie na stworzeniu lokalnej agencji rządu centralnego, pozwala wykorzystać lokalnych wyborców jako mechanizm kontrolny, mobilizujący urzędników do większej efektywności. W tym przypadku wybory pełnią odmienną funkcję niż w modelu Tiebouta. Nie polega ona na ujawnianiu indywidualnych preferencji, lecz na stworzeniu mechanizmu kontroli w warunkach wspólnych preferencji i priorytetów. Mechanizm ten może jednak działać sprawnie tylko wówczas, gdy interesy i preferencje lokalnych wyborców dosyć dobrze współgrają z preferencjami rządu centralnego. W przeciwnym wypadku, znaczenie wyborów jako mechanizmu kontrolującego efektywność lokalnej biurokracji znacząco się obniży.

Należy zwrócić uwagę, że większość teoretycznych argumentów za dostarczaniem dóbr czy świadczeniem usług na szczeblu lokalnym odnosi się raczej do lokalnej kontroli, a nie do lokalnego finansowania [Stiglitz, 2000, s. 742-743]. Poszukiwanie optymalnego poziomu decentralizacji fiskalnej znacznie się komplikuje, jeśli uwzględni się, że polega ona na przekazywaniu na niższe szczeble nie tylko kompetencji kontrolnych, ale również obowiązków i środków zob. szerzej [Owsiak, 1997, s. 110-115]. Sedno sporu dotyczy tego, czy decentralizacja powinna przebiegać w każdym z tych wymiarów niezależnie, czy teź cechują się one względną autonomią. Ważnym czynnikiem komplikującym jest też to, że w odniesieniu do konkretnych instrumentów fiskalnych optymalny poziom decentralizacji może być różny.

Podsumowując można stwierdzić, że kładąc nacisk na wymiar normatywny model federalizmu fiskalnego jest stosunkowo mało przydatny w zrozumieniu ewolucji zastosowanych w różnych krajach rozwiązań oraz tak znacznego, obserwowanego w praktyce, ich zróżnicowania. Ze względu na restrykcyjność przyjętych założeń ograniczona jest w tym względzie również przydatność modelu Tiebouta, który w wymiarze analizy pozytywnej był dominującą konstrukcją teoretyczną [por. Tabellini, 1991].

Chociaż wiedza teoretyczna na temat optymalnego stopnia decentralizacji fiskalnej jest bardzo niekompletna, w minionych latach, w wielu krajach wzmogły się głosy na rzecz jej zwiększenia. Skłoniło to niektórych autorów do skoncentrowania uwagi na niebezpieczeństwach decentralizacji fiskalnej. W poświęconym tej kwestii artykule [Prud'homme, 1995] poddaje analizie trzy rodzaje niebezpieczeństw, przy czym odnosi je do „czystej” decentralizacji, tak jak jest ona rozumiana w teorii federalizmu fiskalnego ${ }^{8}$.

Pierwsze niebezpieczeństwo polega na wzroście nierówności dochodów. Prud'homme wychodzi od wspomnianych już argumentów za centralizacją funkcji redystrybucyjnej, formułowanych na gruncie finansów publicznych, a nastẹpnie wskazuje kilka przyczyn, dla których nieprawdziwa może okazać się teza, że ograniczenie dysproporcji w podziale dochodów prowadzi automatycznie do zmniejszenia się różnic dochodowych między regionami. Na podstawie wyni-

8 Jest to system, w którym „czyste” władze lokalne nakładają „czyste” lokalne podatki i dokonują "czystych" lokalnych wydatków nie korzystając z transferów od rządu centralnego [Prud'homme, 1995]. 
ków badań teoretycznych i empirycznych formuluje wniosek, że system zdecentralizowany jest mniej skuteczny w zmniejszaniu różnic między regionami. Okazuje się, że każde zmniejszenie znaczenia budżetu centralnego w stosunku do szczebli niższego rzędu zwiększa różnice między jednostkami administracyjnymi, ponieważ ogranicza oddziaływanie polityki krajowej ukierunkowanej na ich zmniejszenie. Mechanizm ten ma zarówno charakter statyczny, jak i dynamiczny. Może on prowadzić do wytworzenia się blędnego koła polegającego na tym, że bogatsze jednostki administracyjne będą dysponować większą bazą podatkową mimo stawek podatkowych takich samych lub niższych niż w biedniejszych jednostkach. W pierwszym przypadku, bẹdą one ściągać wyższe podatki i dzięki temu będą mogły świadczyć więcej lokalnych usług publicznych. W drugim przypadku, będą mogly świadczyć te same usługi przy niższych stawkach podatkowych. W obydwu przypadkach przedsiębiorstwa i gospodarstwa domowe będą skłonne osiedlać się w tych jednostkach terytorialnych, co oznaczać będzie zwiększenie bazy podatkowej i luki dochodowej między regionami.

$\mathrm{Z}$ punktu widzenia tematyki niniejszego opracowania najważniejsze jest drugie niebezpieczeństwo decentralizacji, które polega na osłabieniu stabilności gospodarki ze względu na wiẹksze trudności w zastosowaniu polityki makroekonomicznej. Narzędzie stabilizowania gospodarki, jakim jest polityka fiskalna, może być stosowane skutecznie tylko na poziomie centralnym, poniewaź władze lokalne nie mają lub mają niewiele bodźców do podejmowania polityki stabilizacyjnej. Wplyw, jaki władze regionalne mogłyby wywrzeć na łączny popyt czy poziom cen, jest bardzo niewielki. Nawet jeśli taka polityka byłaby skuteczna, to jej pozytywny wpływ dotyczyłby pozostałych regionów, ponieważ subnarodowe jednostki terytorialne cechują się znacznie większą otwartością niż gospodarki narodowe i tym samym „wyciek” efektu stabilizacyjnego byłby bardzo silny. Co więcej, władze regionalne musiałyby ponosić pełny polityczny koszt prowadzonej polityki, mimo że przyniosłaby tylko częściowe korzyści. Oznacza to jednocześnie, że jeśli władze centralne chcą wykorzystać politykę fiskalną do wplywania na łączny popyt, to udział podatków i wydatków centralnych w łącznej ich wielkości musi być wystarczająco wysoki, podobnie jak relacja tych obydwu wielkości do PKB.

Aby pokazać wplyw decentralizacji na skuteczność polityki stabilizacyjnej, Prud'homme posłużył się prostym przykładem liczbowym. Rozważa on kraj, w którym łączne wydatki rządu stanowią 30\% PKB i w którym może on dla celów stabilizacyjnych zwiększyć lub zmniejszyć wydatki o $10 \%$ (co traktuje jako optymistyczne założenie). W pierwszym przypadku, o zdecentralizowanych finansach publicznych, w którym na władze lokalne przypada $60 \%$ łącznych wydatków, rząd centralny byłby w stanie zwiększyć lub zmniejszyć PKB o 1,2\% PKB. Natomiast w gospodarce o scentralizowanych finansach publicznych, wpływ ten wynosiłby $2,7 \%$ PKB. Można przypuszczać, że ta wynosząca 1,5\% PKB różnica może stanowić o tym, czy polityka stabilizacyjna okaże się skuteczna9.

9 Naležy jednak zwrócić uwagẹ, że w ostatnich latach znacznie rzadziej niż w przeszłości formułowane są argumenty za wykorzystywaniem polityki fiskalnej do stabilizowania gospodarki. 
Można ponadto przypuszczać, że polityka fiskalna prowadzona na szczeblu regionalnym będzie mieć charakter pizeciwny niż polityka szczebla centralnego. Może to wynikać np. z odmiennie rozłożonego w czasie cyklu politycznego na szczeblu ogólnokrajowym i lokalnym. Ze względu na zbliżające się wybory władze lokalne będą np. zwiększać wydatki w okresie, gdy rząd centralny będzie starał się ograniczać lączny popyt w gospodarce ${ }^{10}$.

Trzecie analizowane przez Prud'homme'a niebezpieczeństwo decentralizacji dotyczy wymiaru alokacyjnego. Autor ten podaje najpierw przyczyny, dla których założenia federalizmu fiskalnego dosyć słabo przystają do sytuacji występującej w krajach rozwijających się, a następnie koncentruje uwagę na związkach łączących efektywność produkcyjną i alokacyjną z decentralizacją. Interesujące są jego rozważania dotyczące wplywu decentralizacji na zakres zjawiska korupcji. Jego zdaniem, korupcja jest zjawiskiem bardziej powszechnym na szczeblu lokalnym, ponieważ wiẹcej jest na nim okazji do zachowań korupcyjnych, jak również słabsze są ograniczające je przeszkody.

Obawy Prud'homme'a, podzielane również przez [Tanziego, 1996], że decentralizacja jest trudna do pogodzenia z równowagą makroekonomiczną zostały poddane analizie przez [Shaha, 1999]. Autor ten dochodzi do wniosku, że „zdecentralizowane systemy fiskalne oferują potencjalnie większe moźliwości lepszego zarządzania makroekonomicznego niż systemy scentralizowane". Wynika to stąd, że systemy zdecentralizowane wymagają wię̧kszej jasności co do roli poszczególnych graczy (ośrodków podejmowania decyzji) i przejrzystości reguł, od których zależy, czy interakcje między nimi będą zachodzić zgodnie z zasadami fair play. Tak wiẹc zdaniem Shaha, przewaga rozwiązań zdecentralizowanych jest znaczna. Problem polega jednak na tym, że trudno jest w praktyce stworzyć odpowiednie warunki instytucjonalne (szczególnie w krajach rozwijających się) pozwalające, aby te potencjalne przewagi mogly się urzeczywistnić.

Podobne jak Shah stanowisko, aczkolwiek mniej optymistyczne, reprezentuje [Ter-Minassian, 1999]. Również ta Autorka stara się prześledzić implikacje decentralizacji dla stabilności makroekonomicznej. Zwraca uwagę m.in. na to, że implikacje te zależą nie tylko od zakresu, ale i od sekwencji przeprowadzanej decentralizacji. Kluczowe znaczenie ma oczywiście to, czy decentralizacja uprawnień w zakresie wydatkowania środków następuje przed czy po decentralizacji obowiązków dotyczących uzyskiwania przychodów. Równie istotne jest to, aby procesu decentralizacji nie rozpoczynać, zanim nie zostaną uporządkowane finanse publiczne na szczeblu centralnym. Autorka opowiada się także za oparciem decentralizacji na regułach polityki (w sensie dyskusji "reguły kontra działania dyskrecjonalne”). Korzyściami takiego podejścia jest zdecydowanie większa przejrzystość, jednakowy sposób traktowania zainteresowanych stron oraz szansa uniknięcia długotrwałych przetargów między władzą centralną i niższych szczebli. Jednocześnie autorka wskazuje na

10 Prud'homme wskazuje, że sytuacja taka wystąpila w końcu lat 80 . w Wielkiej Brytanii. 
słabe strony podejścia opartego na regułach. Polegają one na małej elastyczności systemu i na sprzyjaniu zachowaniom i praktykom ukierunkowanym na omijaniu reguł. Ter-Minassian wymienia kilka sposobów takich zachowań, a następnie formułuje warunki konieczne do efektywnego działania podejścia opartego na regułach. Skuteczne reguły wymagają wsparcia w postaci:

- jasnych i ujednoliconych standardów rachunkowości dla jednostek administracji rządowej,

- silnego ograniczenia, a najlepiej wyeliminowania operacji pozabudżetowych,

- precyzyjnego zdefiniowania pojęcia dlugu,

- nowoczesnych systemów informacyjnych pozwalających dostarczyć na czas wiarygodnych danych o wszystkich fazach wydatkowania środków i o operacjach finansowych na różnych szczeblach władzy,

- polityk (takich jak prywatyzacja), które minimalizują zakres wykorzystywania przedsiębiorstw oraz instytucji finansowych dla potrzeb rządu.

Ważne wydaje się też wprowadzone przez autorkę rozróżnienie co do optymalnego zakresu władzy centralnej w zależności od tego, czy zaciągane pożyczki pochodzą ze źródeł krajowych czy zagranicznych. Według niej można sformułować cztery argumenty przemawiające za sprawowaniem przez rząd centralny kontroli nad poźyczkami zagranicznymi zaciąganymi przez władze niższego szczebla:

- polityka zagranicznego długu publicznego łączy się bardzo ściśle z innymi rodzajami polityki makroekonomicznej (pieniężną, kursową oraz zarządzaniem rezerwami zagranicznymi), które znajdują się w gestii władz centralnych (przede wszystkim banku centralnego);

- dobrze skoordynowane działania prowadzone na międzynarodowych rynkach instrumentów dłużnych pozwalają uzyskać lepsze warunki niż w przypadku działań rozdrobnionych;

- pogorszenie się ocen formułowanych przez firmy ratingowe w stosunku do jednego z lokalnych pożyczkobiorców może - poprzez efekt „zakażenia” obniżyć oceny innych pożyczkobiorców (zarówno z sektora publicznego, jak i prywatnego);

- zagraniczni pożyczkodawcy domagają się zazwyczaj oficjalnych gwarancji rządu centralnego dla pożyczek zaciąganych na poziomie subnarodowym. Zdaniem autorki, zdecydowanie mniej uzasadnione są natomiast argumenty za kontrolowaniem przez rząd centralny pożyczek zaciąganych przez jednostki niższych szczebli na rynku krajowym.

Przeprowadzona analiza skłania Ter-Minassian do sformułowania ogólnych wniosków na temat sposobów zminimalizowania makroekonomicznych kosztów decentralizacji. Po pierwsze, im większy jest zakres przeniesienia na niższe szczeble uprawnień i obowiązków w zakresie wydatków i pozyskiwania środków, tym bardziej ważne staje się prowadzenie przez rząd centralny aktywnego dialogu z jednostkami niższych szczebli i włączenie je w działania makroekonomiczne i dostosowawcze. W przyszłości istotną rolę w tym względzie może odegrać naszkicowany przez autorkę tzw. model federalizmu kooperatywnego. Po drugie, ogniwa niższego szczebla wymagają twardych ogra- 
niczeń budżetowych - wszechstronnych, przejrzystych i skutecznie monitorowanych ograniczeń dotyczących moźliwości zadłużania się.

Również [Hommes, 1996; wg Rezka, 1999] zwraca uwagę na warunki, od których zależy skuteczna decentralizacja. Ogólnie rzecz biorąc, korzystne efekty ekonomiczne decentralizacji zależą od przezwyciężenia instytucjonalnych konfliktów i politycznych dylematów. Pierwszym warunkiem jest dysponowanie przez rząd centralny umiejętnością podjęcia właściwej decyzji dotyczącej tego, kiedy należy wkroczyć w lokalną autonomię ze względu na wymóg stabilności makroekonomicznej, a kiedy należy powstrzymać się od interwencji. Za drugi kluczowy warunek decentralizacji autor ten uznaje dysponowanie przez władze lokalne uprawnieniami do uzyskiwania przychodów (finansowa wystarczalność i autonomia), natomiast trzecim jest dobrze funkcjonująca lokalna demokracja zapewniająca sprawny mechanizm podejmowania decyzji.

Podsumowując można stwierdzić, że mimo postępu w badaniach nie wyłoniła się jeszcze pewna ogólna perspektywa teoretyczna, która uwzględniałaby wątki pomijane przez model federalizmu fiskalnego. Być może rację ma [Bird, 1995; wg Rezka, 1999], że dalsze badania nad decentralizacją fiskalną powinny być prowadzone w ramach dwu uzupełniających się perspektyw - federalizmu fiskalnego oraz finansów federalnych (federal finance). Perspektywa finansów federalnych odnosi się do sytuacji, w której zarówno granice administracyjne oraz funkcje dotyczące podatków i wydatków są określone konstytucyjnie, transfery między różnymi szczeblami władzy mają charakter bezwarunkowy (i ogólnie rzecz biorąc wyrównujący poziom dochodów), a relacje między rządem centralnym i władzami niższego szczebla mają postać przetargu między „pryncypalami”, bez dominacji ze strony centrum. Natomiast perspektywa badawcza federalizmu fiskalnego znajduje zastosowanie w sytuacji, gdy rząd centralny podejmuje decyzje co do struktury terytorialnej, przyporządkowania funkcji określonym szczeblom, transferów i innych rozwiązań instytucjonalnych. Zdaniem [Rezka, 1999, s. 102], perspektywa finansów federalnych wprowadza nowy sposób rozpatrywania decentralizacji fiskalnej i pozwala uwzględnić alternatywne ujęcia procesu kolektywnego podejmowania decyzji, takie jak teoria wyboru publicznego ${ }^{11}$.

\section{Decentralizacja fiskalna w świetle badań empirycznych}

Ogólnie rzecz biorąc, badania empiryczne nad decentralizacją fiskalną są stosunkowo słabo zaawansowane i ze względu na brak odpowiednich danych koncentrowały się one na krajach rozwiniętych. Dopiero w ostatnich latach, przede wszystkim ze względu na podejmowane przełomowe reformy gospodarcze i polityczne, badaniami objęte zostały również kraje na średnim i niskim poziomie rozwoju.

11 Warto jednak zaznaczyć, że zdaniem niektórych badaczy [Wagner, 1997], w analizowaniu zjawisk ze sfery finansów publicznych bardziej przydatna niż teoria wyboru jest teoria wymiany. 
Jedna z bardziej znaczących prób odnoszących siẹ do krajów wysoko rozwiniętych została podjęta przez [Hughesa i Smitha, 1991]. Celem badań było naświetlenie charakteru finansowych związków między władzami centralnymi i lokalnymi w 19 krajach OECD, które autorzy podzielili na cztery grupy. Jeden z najbardziej zaskakujących wyników dotyczył bardzo dużej różnorodności przyjętych na poziomie lokalnym rozwiązań (w krajach, które pod innymi względami są do siebie podobne) oraz braku jednego dominującego modelu. Komentując ten zaskakujący wynik [Tabellini, 1991] wysuwa hipotezę, że być może struktura opodatkowania na szczeblu lokalnym nie jest specjalnie waźna, natomiast czynnikiem odgrywającym istotną rolę jest wielkość i podział ogólnego ciężaru podatkowego na szczeblu centralnym. Drugi z zaskakujących rezultatów dotyczy tego, że różnorodność rozwiązań instytucjonalnych w dziedzinie podatków i wydatków jest bardzo słabo powiązana ze zmiennymi charakteryzującymi politykę fiskalną na szczeblu krajowym i na niższych szczeblach.

Niektóre spośród pozostałych wyników uzyskanych przez Hughesa i Smitha są następujące:

- w większości badanych krajów występowało z biegiem czasu wyraźne przesunięcie od podatków szczególnych do ogólnych;

- udział dochodów podatkowych władz lokalnych utrzymywal się na stabilnym poziomie;

- zróżnicowanie lokalnych wydatków jest znacznie mniejsze niż lokalnych podatków;

- brak jest wyraźnej zależności między zakresem odpowiedzialności w zakresie wydatków przyporządkowanych określonemu szczeblowi władzy a łącznymi przychodami, jakie może on uzyskać z przyznanych mu uprawnień podatkowych;

- dla wszystkich władz subnarodowych łączne przychody (jako udział w PKB) są dodatnio skorelowane z udziałem podatków lokalnych i ujemnie skorelowane z udziałem dotacji w łącznych przychodach.

Analiza ekonometryczna przeprowadzona przez [Burkiego et al., 1999] jest z punktu widzenia niniejszego opracowania szczególnie interesująca, ponieważ dotyczy zagrożeń płynących z decentralizacji fiskalnej dla stabilności makroekonomicznej. W badaniu wykorzystano dane dla okresu 1980-94 obejmujące 32 kraje rozwinięte i rozwijające się. Za zmienną zależną przyjęte zostały wydatki pierwotne rządu centralnego (uwzględniające transfery i deficyt pierwotny), natomiast głównymi zmiennymi niezaleźnymi - albo łączne subnarodowe wydatki i podatki lub opóźnione subnarodowe łączne deficyty budżetowe. Uwzględnione zostały również standardowe zmienne kontrolne, takie jak wzrost PKB, inflacja, urbanizacja, niezależność banku centralnego oraz istotne zmiany polityczne.

Uzyskane wyniki badań przekrojowych sugerują, że: a) decentralizacja wydatków w drodze transferów zwiększa łączne rozmiary sektora rządowego, b) w stopniu, w jakim władze subnarodowe finansują swoją działalność za pomocą własnych podatków, wielkość centralnego sektora rządowego zmniejsza 
się w podobnym stopniu, w jakim wzrastają wydatki na poziomie subnarodowym, w związku z czym ogólna wielkość sektora publicznego nie zmienia się. $\mathrm{Z}$ badań tych wynika również, że w długim okresie kraje, które przeprowadziły decentralizację nie mają, przeciętnie rzecz biorąc, wyższego poziomu deficytu niż kraje bardziej scentralizowane. Autorzy przypuszczają, że kraje te stworzyły odpowiednie instytucje oraz podniosły podatki, aby wyeliminować obawy związane z deficytem budżetowym.

Do wyraźnie odmiennych wniosków prowadzi analiza oparta nie na poziomach przyjętych wielkości, lecz na ich zmianach. Okazuje się, że wówczas wzrost wydatków i deficytów na poziomie subnarodowym prowadzi do większych wydatków i deficytów rządu centralnego (w proporcji prawie jeden do jeden). Jest to spójne z sytuacją, kiedy to rząd centralny udziela pomocy finansowej jednostkom niższego szczebla, gdy zanadto się zadłużyły. Interpretując uzyskane wyniki autorzy zwracają uwagę, że wykorzystanie w analizie rachunku różniczkowego oznacza, iż pozostają one pod silnym wplywem krajów i okresów charakteryzujących siẹ szybkimi zmianami wydatków i deficytów na poziomie krajowym i subnarodowym (czyli decentralizacją). Autorzy sądzą, że wyniki te dostarczają niezwykle silnego argumentu przeciwko szybkiej decentralizacji bez odpowiednich mechanizmów zabezpieczających. Sugerują one bowiem, że przejściu do zdecentralizowanego systemu finansów publicznych towarzyszą zazwyczaj problemy z utrzymaniem równowagi makroekonomicznej.

W podsumowaniu tej części badań autorzy wskazują, że uzyskane wyniki rzucają światło na niektóre obawy przed decentralizacją fiskalną, jakie formułowane są w opracowaniach teoretycznych. Następujące obawy znajdują uzasadnienie w rezultatach badań:

- decentralizacja oparta na transferach od wladz centralnych, typowa w krajach Ameryki Łacińskiej, zwiększa rozmiary całego sektora rządowego;

- wzrost deficytu na szczeblu subnarodowym prowadzi do wzrostu wydatków na poziomie krajowym, zwiększenia deficytu oraz niestabilności makroekonomicznej.

Inne obawy nie znalazly natomiast uzasadnienia, ponieważ okazało się, że:

- decentralizacja oparta na lokalnych podatkach nie zwiększa rozmiarów sektora rządowego w okresach długich (w stanie ustalonym),

- w stanie ustalonym decentralizacja nie jest powiązana ani z większym, ani z mniejszym poziomem deficytu budżetowego.

W ostatnich latach, w badaniach odnoszących się do większej grupy krajów, podejmowano również próby określenia, czy decentralizacja fiskalna ma wpływ na wzrost gospodarczy. Obejmujące 40 krajów badanie oparte na modelu Barro i Sala-i-Martina uzupełnionego o zmienne charakteryzujące decentralizację fiskalną i strukturę finansową pokazuje silną dodatnią korelację między stopniem decentralizacji a wzrostem per capita [Oates, 1996].

$\mathrm{Z}$ analiz teoretycznych wynika, że sposoby pozyskiwania środków przez władze lokalne i regionalne mogą mieć istotny wplyw na efektywność ich wydatkowania. Przyjmuje się, że transfery, aczkolwiek wygodne jako narzędzia od 
strony technicznej, mogą stwarzać bodźce do niekorzystnych zachowań na poziomie lokalnym, ponieważ - inaczej niż lokalne podatki - są one traktowane jako „pieniądze innych ludzi”. Dowodów empirycznych w tym względzie jest niewiele, a ich interpretacja jest niejednoznaczna. Tablica 1 obrazuje różnice wystẹpujące między krajami w zakresie źródeł przychodów władz regionalnych i lokalnych. Dane dotyczące krajów OECD wydają się wskazywać, że poleganie w dużym stopniu na transferach nie musi siẹ przekładać na działania korupcyjne i niegospodarność w wykorzystywaniu środków. Tablica 1 pokazuje, że udział transferów w dochodach władz lokalnych jest w Wielkiej Brytanii wyższy niż w jakimkolwiek kraju latynoamerykańskim, a ich udział w dochodach władz regionalnych jest w Hiszpanii wyższy niż w Brazylii czy Argentynie. Jak sugerują autorzy opracowania [Burki et al., 1999, s. 30], wpływ na zachowania lokalnych polityków mają więc raczej, przede wszystkim, warunki na jakich dokonywane są transfery. Transfery podlegające negocjacjom, czyli takie, które dokonywane są w zamian za lokalne poparcie dla polityków działających na szczeblu centralnym, mogą zmniejszać skuteczność lokalnych decyzji. Z kolei transfery zarezerwowane dla władz subnarodowych znajdujących się w kryzysie finansowym mogą zachęcać je do podejmowania ryzykownych przedsięwzięć (moral hazard). Tego rodzaju transfery byly rozpowszechnione w krajach Ameryki Łacińskiej w latach 60. i 70., ale obecnie większość ich ma postać stałego udziału w określonych przychodach rządu centralnego i środki są rozdysponowywane między szczeble subnarodowe według z góry określonej formuly.

Tablica 1

Żrodla dochodów budżetowych w wybranych krajach, w \%

\begin{tabular}{|l|c|c|c|c|c|c|}
\hline \multirow{2}{*}{ Kraj } & \multicolumn{3}{|c|}{ Prowincje } & \multicolumn{3}{c|}{ Whadze lokalne } \\
\cline { 2 - 7 } & podatki & transfery & $\begin{array}{c}\text { dochody } \\
\text { pozapodatkowe }\end{array}$ & podatki & transfery & $\begin{array}{c}\text { dochody } \\
\text { pozapodatkowe }\end{array}$ \\
\hline Argentyna & 36 & 57 & 7 & & & \\
\hline Australia & 36 & 40 & 24 & 55 & 17 & 28 \\
\hline Brazylia & 67 & 17 & 9 & 41 & 44 & 15 \\
\hline Kanada & 67 & 20 & 14 & 41 & 44 & 15 \\
\hline Francja & & & & 48 & 34 & 18 \\
\hline Niemcy & 68 & 19 & 13 & 32 & 32 & 36 \\
\hline Meksyk & 7 & 81 & 12 & 18 & 64 & 18 \\
\hline Peru & 3 & 94 & 3 & 15 & 57 & 28 \\
\hline Hiszpania & 19 & 78 & 3 & 52 & 36 & 12 \\
\hline W. Brytania & & & & 16 & 72 & 12 \\
\hline USA & 50 & 22 & 28 & 41 & 37 & 22 \\
\hline
\end{tabular}

Uwaga: Podatki pobierane centralnie z myślą o wladzach subnarodowych są klasyfikowane jako podatki subnarodowe. Dane dotyczạce regionów i departamentów we Francji są uwzględnione wraz z gminami we „władzach lokalnych"; dane dotyczące Niemiec nie uwzględniają płatnosci wyrównawczych między landami.

Źródło: GFS 1997, wg Burki et al. 1999, s. 28 
Również [Shah, 1999, s. 48-49] wskazuje na różnice między krajami rozwiniętymi i rozwijającymi się dotyczące dominującego rodzaju transferów. W krajach rozwiniętych występują transfery pomagające osiągnąć standardy ogólnokrajowe oraz transfery ukierunkowane na wyrównywanie różnic międzyregionalnych. Natomiast w krajach rozwijających się dominują transfery mające zapewnić poparcie polityczne (pork-barrel variety), a transfery wyrównawcze o wyraźnie określonych standardach nie występują. Przy ograniczonej decentralizacji podatków lub jej braku skomplikowane, uwzględniające wiele czynników transfery finansują większość wydatków na poziomie subnarodowym. Prowadzi to do uzależnienia od transferów i zniechęca do odpowiedzialnego i poddającego się publicznej ocenie zarządzania finansami lokalnymi. Shah przytacza wyniki badań empirycznych potwierdzające te zależności. Z badań tych wynika, że równoczesna decentralizacja uprawnień w zakresie wydatków i podatków pozwala bezpośrednio powiązać koszty i korzyści dostarczania dóbr i usług publicznych i tym samym prowadzi do zmniejszenia wielkości sektora publicznego. Natomiast decentralizacja wydatków powiązana z udziałem w dochodach budżetu centralnego eliminuje związek między odpowiedzialnością i publiczną oceną (accountability) i przez to nie pozwala na osiągnięcie tego korzystnego rezultatu. Dominujące w krajach rozwijających się formy transferów prowadzą w konsekwencji do sytuacji, w której władze niższych szczebli podejmują decyzje sprzeczne z ich długookresowym interesem ekonomicznym. Ogranicza to naturalne reakcje dostosowawcze i uruchamia mechanizm niekorzystnych sprzężeń zwrotnych utrwalający niski poziom dochodów w regionach słabo rozwiniętych.

Doświadczenia różnych krajów rzucają światło na zależność miẹdzy decentralizacją fiskalną a stabilnością makroekonomiczną. Okazuje się [Shah, 1999, s. 41-42], że rządy centralne naruszają często wskaźniki przyjęte przez kraje Unii Europejskiej w ramach kryteriów z Maastricht, natomiast rządy subnarodowe robią to zdecydowanie rzadziej. Prawidłowość ta odnosi się zarówno do zdecentralizowanych krajów federalnych (Argentyna, Brazylia, Kanada, Niemcy), jak i scentralizowanych krajów federalnych (Australia, Indie, Pakistan). Jeszcze gorzej pod tym względem wypadają kraje o systemie unitarnym ${ }^{12}$

Więcej światła na makroekonomiczne zagrożenia wynikające z decentralizacji fiskalnej rzucają szczegółowe badania dotyczące poszczególnych krajów. Bardzo pouczający pod tym względem jest przykład Argentyny i Brazylii. Porównanie sposobu przeprowadzenia reform w tych krajach wskazuje na bardzo ważną rolę, jaką odgrywa narzucenie władzom subnarodowym twardego ograniczenia budżetowego. Zdaniem [Burkiego et al., 1999, s. 39-40], analizę porównawczą ułatwia wyróżnienie dwunastu czynników instytucjonalnych, zarówno fiskalnych, jak i politycznych, które wplywają na jakość zarządzania zdecentralizowanymi finansami publicznymi w krajach demokratycznych:

- twarde ograniczenia budżetowe wobec władz centralnych i subnarodowych,

12 Podjęte w ostatnich latach reformy modyfikują w znacznym stopniu ten ogólny wniosek. 
- transfery oparte na regułach,

- ograniczenia dotyczące zaciągania pożyczek:

- ograniczenia ex ante,

- konsekwencje ex post i wynikające stąd bodźce,

- egzekwowanie platności przez władze subnarodowe,

- regulacje nie pozwalająca na umarzanie złych kredytów udzielonych przez banki niewiarygodnym władzom lokalnym,

- niezależność banku centralnego,

- autonomia władz niższych szczebli w ramach twardego ograniczenia budżetowego,

- zdolność kontrolowania wydatków i kosztów,

- zdolność zwiẹkszania dochodów,

- polityczna zdolność władz centralnych egzekwowania twardego ograniczenia budżetowego,

- uprawnienia prezydenta,

- uprawnienia gubernatorów,

- dyscyplina w partiach politycznych,

- system wyborczy.

Przed 1991 r. deficyt budżetowy rządu centralnego, jak i władz niższego szczebla był głównym problemem makroekonomicznym Argentyny, poniewaź prowadził do hiperinflacji. Ocenia się, że deficyty na szczeblu subnarodowym, w połączeniu z pośrednim dofinansowywaniem banków znajdujących się w trudnej sytuacji, były odpowiedzialne przynajmniej w polowie za deficyt całego sektora publicznego, który był przyczyną hiperinflacji. Rozpoczęty w $1991 \mathrm{r}$. program stabilizacyjny okazał się również skuteczny w zakresie narzucenia wladzom lokalnym twardych ograniczeń budżetowych przede wszystkim w wyniku wprowadzenia systemu izby walutowej (currency board) i nowych zasad obsługi długu publicznego. Zabronione zostało udzielanie przez federalne Ministerstwo Skarbu bezpośrednich poźyczek prowincjom oraz udzielanie przez bank centralny gwarancji w przypadku kredytów udzielanych przez banki władzom regionalnym i lokalnym. W latach 1991-1994 realna wartość dochodów władz subnarodowych wzrosła silnie w wyniku zarówno podatków lokalnych, jak i udziału w dochodach władz centralnych. Jednocześnie rząd federalny obniżył tempo wzrostu własnych wydatków poniżej tempa wzrostu dochodów oraz wynegocjował z prowincjami zaakceptowanie przez nie dodatkowego zakresu odpowiedzialności. Prowadzenie polityki zrównoważonego budżetu na poziomie i wspieranie tym samym programu dostosowawczego na szczeblu centralnym nie byłoby prawdopodobnie możliwe, gdyby gubernatorzy prowincji nie należeli do tej samej partii co prezydent.

Kryzys meksykański 1994-1995 r. był dobrym testem skuteczności przyjętych rozwiązań, a jednocześnie ulatwił utrzymanie dotychczasowego kursu polityki makroekonomicznej. Odrzucając bowiem starania prowincji o zwiększenie transferów rząd centralny mógł bowiem użyć argumentu, że groziłoby to utratą dotychczasowych korzyści ze stabilizacji i załamaniem się systemu currency board. Początkowo w okresie kryzysu prowincje próbowały się zadłużać, 
ale zjawisko to nie przybrało niebezpiecznych rozmiarów, ponieważ wladze centralne wysłały jednoznaczny sygnal, że jakakolwiek pomoc w tym zakresie jest możliwa tylko na warunkach komercyjnych.

Natomiast w Brazylii pierwsze lata demokratyzacji przyniosly restrukturyzację zadlużenia wladz stanowych wobec zagranicznych kredytodawców. Trzy lata później przeprowadzono restrukturyzacjẹ zadłużenia władz stanowych wobec federalnych instytucji finansowych. W wyniku tych działań uksztaltowało się przekonanie, że rząd federalny będzie skłonny umorzyć część długu, gdy władze niższego szczebla bẹdą się tego domagać. W rezultacie w kolejnych latach władze stanowe bardzo silnie zadłużyly się zarówno emitując obligacje, jak i zaciągając kredyty w bankach państwowych. Sytuacja podlegała pewnym cyklicznym zmianom - można wyróżnić cztery rundy kryzysu i restrukturyzacji długu władz stanowych: 1988 r., 1993 r., 1994-95 i 1998-99 [Burki et al., 1999, s. 43; zob. też Rezk, 1999, s. 104-113].

W przeciwieństwie do krajów latynoamerykańskich, kraje azjatyckie cechował tradycyjnie konserwatyzm fiskalny. System fiskalny w tych krajach cechuje się (z wyjątkiem Chin) wysokim stopniem centralizacji. System taki występuje nawet w takich krajach, jak Indonezja (której położenie geograficzne, wydawałoby się, powinno sprzyjać decentralizacji) oraz Malezja, która jest państwem federalnym zob. szerzej [Fukusaku, 1999].

\section{Bibliografia}

Atkinson, A.B. (1996), Growth and the Welfare State. Is the Welfare State Necessarily Bad for Economic Growth?, "New Economy”.

Begg, D., Wyplosz, C. (1999), How Big a Govermnet? Transition Economy Forecasts Based on OECD History, paper presented at the $5^{\text {th }}$ Dubrovnik Conference on Transition Economies, June, maszynopis.

Bird, R.M. (1995), Fiscal Federalism and Federal Finance, „Annales de las 28 Jornadas de Finanzas Publicas".

Brożek, J. (2000), Finanse samorzqdu terytorialnego - pienvszy rok funkcjonowania, w: Raport o stanie funansowym panistwa w 1999 roku, Instytut Finansów Wyższej Szkoly Ubezpieczeń i Bankowosci, Warszawa.

Burki, S.J., Perry, G.E., Dillinger, W.R. (1999), Beyond the Center: Decentralizing the State, The World Bank, Washington.

Cordes, J.J. (1997), Reconciling Normative and Positive Theories of Government, „American Economic Review", nr 2.

Entering (2000), Entering the 2I Century. World Development Report 1999/2000, The World Bank, Washington.

From (1996), From Plan to Market. World Development Report 1996, The World Bank, Washington.

Fukusaku, K. (1999), Fiscal Decentralisation and Macroeconomic Govemance: Asian Perspectives, w: Fukusaku, K., de Mello, L.R. (red.), Fiscal Decentralisation in Emerging Economies. Govemance Issues, Development Centre, OECD, Paris.

Giddens, A. (1999), Trzecia droga, KiW, Warszawa. 
Gilowska, Z. (1999), System finansowy jednostek samorzqdu terytorialnego, w: Gorzelak, G. (red.). Decentralizacja terytorialnej organizacji kraju: zalozenia, przygotowanie, ustawodawstwo. „Raporty CASE", nr 21, Centrum Analiz Spoleczno-Ekonomicznych, Warszawa.

Hommes, R. (1996), Conflicts and Dilemmas of Decentralisation, .Annual World Bank Conference on Development Economics. 1995".

Hughes, G., Smith, S. (1991), Economic Aspects of Decentralized Govemment: Structure, Functions and Finance, "Economic Policy”, November.

Lindert, P. (1996), Does Social Spending Deter Economic Growth?, „Challenge”, May-June,

Milgrom, P., Roberts, J. (1992), Economics, Organization and Management, Prentice-Hall, Englewood Cliffs.

Musgrave, R.A. (1959), The Theory of Public Finance, McGraw Hill, New York.

Musgrave, R.A. (1997), Reconsidering the Fiscal Role of Govemment, „American Economic Review", nr 2 .

Owsiak, S. (1997), Finanse publiczne. Teoria i praktyka, PWN, Warszawa.

Oates, W. (1996), Comment, „Annual World Bank Conference on Development Economics. 1995".

Prud'homme, R. (1995), The Dangers of Decentralization, „World Bank Research Observer", nr 2.

Rezk, E. (1999), Experiences of Decentralisation and Intergovermental Fiscal Relations in Latin America, w: Fukusaku, K., de Mello, L.R. (red.), Fiscal Decentralisation in Emerging Economies. Govemance Issues, Development Centre, OECD, Paris.

Shah, A. (1999). Fiscal Federalism and Macroeconomic Govemance: for Better or for Worse?, w: Fukusaku, K., de Mello, L.R. (red.), Fiscal Decentralisation in Emerging Economies. Governance Issties, Development Centre, OECD, Paris.

Slemrod, J. (1995), What Do Cross-Country Studies Teach about Govemment Involvement, Prosperity, and Economic Growth?. „Brookings Papers on Economic Activity”, nr 2.

Stiglitz, J.E. (2000), Economics of the Public Sector, wyd. 3, Norton, New York.

Tabellini, G. (1991), Discussion, „Economic Policy”, November.

Ter-Minassian, T. (1999), Decentralisation and Macroeconomic Management, w: Fukusaku, K., de Mello, L.R. (red.), Fiscal Decentralisation in Emerging Economies. Govemance Issues, Development Centre, OECD, Paris.

Tanzi, V. (1996), Fiscal Federalism and Decentralisation: A Review of Some Efficiency and Macroeconomic Aspects, „Annual World Bank Conference on Development Economics. 1995".

Wagner, R.E. (1997). Choice, Exchange, and Public Finance, „American Economic Review”, nr 2. 